\title{
Lipoprotein Lipase
}

National Cancer Institute

\section{Source}

National Cancer Institute. Lipoprotein Lipase. NCI Thesaurus. Code C104616.

Lipoprotein lipase ( $475 \mathrm{aa}, \sim 53 \mathrm{kDa}$ ) is encoded by the human LPL gene. This protein is involved in the metabolism of triglycerides. 